\title{
Autogenously derived regenerative cell therapy for venous leg ulcers
}

\author{
Ali Aycan Kavala, Saygin Turkyilmaz
}

Department of Cardiovascular Surgery, Bakirkoy Dr Sadi Konuk Training and Research Hospital, Istanbul, Turkey

Submitted: 13 August 2018

Accepted: 9 October 2018

Arch Med Sci Atheroscler Dis 2018; 3: e156-e163

DOI: https://doi.org/10.5114/amsad.2018.81000

Copyright $\odot 2018$ Termedia \& Banach

\section{Abstract}

Introduction: Venous leg ulcers (VLUs), which arise from chronic venous insufficiency in the lower limbs, are a major cause of morbidity and significantly negatively impact patients' health-related quality of life. Treatment of venous ulcers can be either conservative or surgical. Despite appropriate treatment, VLUs can be resistant to healing. Clinical results of treatment of venous foot ulcers with adipose-derived autologous stem cells, which did not improve despite the surgical treatment of the underlying venous pathology in the following case series, are reported.

Material and methods: Between April 2015 and January 2016, a total of 31 patients who had undergone surgery for underlying venous pathology but the venous ulcer had not healed were included in the study. The mean venous ulcer size was $3.6-6.2 \mathrm{~cm}$ (range: 2 to $8 \mathrm{~cm}$ by 3 to $9 \mathrm{~cm}$ ). All patients were treated with adipose-derived autologous stem cells prepared using the MyStem Regenerative Adipose-Derived Stem Cell Purification Kit (MyStem LLC, USA). The ulcer diameter was measured and recorded in the third, sixth and twelfth months. The follow-up time was 12 months after ulcer healing.

Results: Eighteen ulcers demonstrated complete healing at the $12^{\text {th }}$ month. Thirteen ulcers exhibited serious contraction and epithelialization even though the ulcer was not completely closed. At the $12^{\text {th }}$ month, the ulcer size was reduced by $96.00 \pm 1.74 \%$ in these patients. The reduction in the ulcer area based on the month analyzed was significant $(p=0.001 ; p<0.01)$. After the ulcers healed, the patients were followed for recurrence for one year. Recurrent ulcers were observed at the treated sites in 3 of 31 patients (9\%). No adverse events, such as infection, inflammation, or tissue reactions, were observed.

Conclusions: Application of cell therapy in venous leg ulcer is currently used exclusively in patients not responding to the standard treatment. Autogenously derived regenerative cell therapy for VLUs can be considered as an additional treatment to primary surgical therapy.

Key words: venous insufficiency, leg ulcer, autologous stem cells.

\section{Introduction}

Venous leg ulcers (VLUs), which arise from chronic venous insufficiency in the lower limbs, are a significant therapeutic challenge and a major cause of morbidity worldwide [1]. The prevalence of venous leg ulcers has been reported to be 1-1.5\% [2]. Risk factors, such as obesity, congestive heart failure and older age, increase the prevalence [3].

\author{
Corresponding author: \\ Saygin Turkyilmaz \\ Department of \\ Cardiovascular Surgery \\ Bakirkoy Dr Sadi \\ Konuk Training and \\ Research Hospital \\ Istanbul, Turkey \\ Phone: +90 5052557993 \\ E-mail: sygnty@hotmail.com
}


Venous leg ulcer is a term defining an area of epidermal discontinuity that persists for four weeks or more and develops secondarily to chronic venous insufficiency. This inflamed lesion may involve complete loss of the epidermis or loss of a portion of the dermis and subcutaneous fat. Venous hypertension, which is the underlying pathophysiology, is caused by venous reflux or insufficiency of the calf muscle pump or venous obstruction, which affects the superficial venous system (lesser and greater saphenous vein), the deep venous system, or the perforator veins between those systems [4].

Treatment of venous ulcers can be either conservative (local treatment, bed rest, leg elevation and compression) or surgical. The surgical treatment option depends on venous insufficiency. Venous insufficiency can present with different reflux patterns involving deep, superficial and perforating veins alone or in combination [5, 6]. Regarding superficial vein reflux, surgery choices involve high ligation with or without stripping or radiofrequency (RF) ablation of the great or lesser saphenous veins [7, 8]. Avulsion of varicosities can be added to the treatment. If perforator vein insufficiency is noted, ligation of incompetent perforating veins can be necessary [4-6, 9]. However, not all VLU patients are candidates for surgery due to comorbid conditions; compression, wound care and debridement still remain the first-line treatments of such disabling diseases.

Despite appropriate treatment, VLUs can be resistant to healing, and recurrences frequently occur. This feature may be due to persistent chronic inflammatory processes in tissues. We hypothesized that adipose-derived autologous stem cell (ASC) therapy, which is effective in chronic wound healing, could be beneficial in these patients to enhance tissue repair and decrease the relapse rate [7]. Stem cells are found in some tissues and have the potential to transform into different tissues, which if necessary create many cells and maintain their survival. Stem cells are undifferentiated cells with the ability to transform into specific cells with appropriate chemical signals. In recent years they have been shown to be a variety of stem cell types, and the newest and most promising are adipose tissue-derived mesenchymal stem cells (ADMSCs). These cells are also used in many clinical applications such as stromal vascular fraction (SVF). Adipose tissue-derived mesenchymal stem cells are multipotent, stromal cells with a surface-dependent, specific surface phenotype (CD45-, CD31-, CD34+, CD49d+, etc.) showing fibroblastic morphology like all other mesenchymal stem cells. Functions of adipose tissue-derived progenitor cells include anti-inflammatory, immunomodulation, trophic support, angiogenesis through cytokine secretion, differentiation, new tissue making, revascularization, and antiapoptosis to stop cell death [10].

In particular, ADMSCs have attracted a lot of attention in recent years as an alternative to the use of cells that are derived from bone marrow. This is due to the ease with which they can be isolated and expanded and their large number within the adipose tissue; the frequency ranges from $1: 100$ to $1: 1500$ cells, which far exceeds the frequency of mesenchymal stem cells in bone marrow [11, 12]. There is only 1 per 100,000 nucleated cells of mesenchymal stem cells in bone marrow and their quantity declines with age [13].

The ADMSCs are multi-potent stem cells and have characteristics similar to bone marrow-mesenchymal stem cells, as demonstrated by their expression of the same cell surface markers, their similar gene expression profiles and their similar differentiation potentials [14]. For this reason, ADMSCs are able to form bone, cartilage, muscle and fat, under appropriate stimuli. They are multi-potent and secrete a variety of growth factors [15] such as basic fibroblast growth factor (bFGF), keratinocyte growth factor (KGF), transforming growth factor $\beta$ (TGF- $\beta$ ), hepatocyte growth factor (HGF), and vascular endothelial growth factor (VEGF) [16].

In this case series, we applied adipose-derived autologous stem cells to venous leg ulcers simultaneously with the treatment of underlying causative venous hypertension and reported clinical outcomes.

\section{Material and methods}

Between April 2015 and January 2016, 31 patients who underwent venous surgery for underlying pathologies and venous ulcers had not healed were included in the study.

A total of 31 patients with venous leg ulcers were included in the study. In total, 25 patients were male and 6 patients were female. Patient age ranged between 29 and 61 years (mean: 44.8 \pm 9 ). Patients underwent a standardized leg ulcer assessment, consisting of a medical history and clinical examination: an ankle brachial pressure index assessment and color venous duplex scanning. Based on clinical findings of venous disease, all patients were classified as class 6 according to the Comprehensive Classification System for Chronic Venous Disorders (CEAP) classification. All of the patients were C6 (Venous leg ulcers) according to the CEAP classification. The mean venous ulcer size was $3.6 \times 6.2 \mathrm{~cm}$ (range: 2 to $8 \mathrm{~cm}$ $\times 3$ to $9 \mathrm{~cm}$ ).

Patients were evaluated for symptomatic venous insufficiency with duplex ultrasound (US) (128 XP 10 color flow ultrasound scanner; Acuson, 
Table I. Patient characteristics

\begin{tabular}{|lcc|}
\hline Parameter & \multicolumn{1}{c|}{ Value } \\
\hline Age [years] & $\begin{array}{c}\text { Min.-max. } \\
\text { (median) }\end{array}$ & 29-61 (46) \\
\cline { 2 - 3 } & Mean \pm SD & $44.81 \pm 9.48$ \\
\hline Gender, $n$ (\%) & Female & $6(19.4)$ \\
\cline { 2 - 3 } & Male & $25(80.6)$ \\
\hline $\begin{array}{l}\text { Perforant venous } \\
\text { insufficiency, } n \text { (\%) }\end{array}$ & $11(35.5)$ \\
\hline $\begin{array}{l}\text { Great saphenous venous } \\
\text { insufficiency, } n \text { (\%) }\end{array}$ & Grade 3 & $9(29.0)$ \\
\cline { 2 - 3 } $\begin{array}{l}\text { Great saphenous vein } \\
\text { diameter [cm] }\end{array}$ & $\begin{array}{c}\text { Min.-max. } \\
\text { (median) }\end{array}$ & $52(71.0)$ \\
\cline { 2 - 3 } & Mean \pm SD & $7.48 \pm 1.09$ \\
\hline First time ulcer, $n$ (\%) & & $31(100.0)$ \\
\hline CEAP, $n$ (\%) & C6 & $31(100.0)$ \\
\hline $\begin{array}{l}\text { Great saphenous vein } \\
\text { radiofrequency ablation, } \\
n \text { (\%) }\end{array}$ & & $30(96.8)$ \\
\hline Perforant ligation, $n$ (\%) & & $11(35.5)$ \\
\hline
\end{tabular}

Mountain View, Calif.). Starting at the saphenofemoral junction, the deep, superficial, and perforating veins were assessed with Doppler scan flow patterns. Compression maneuvers and examination of flow patterns with augmentation identified the reflux and defined the competency of perforator veins. The diagnosis of superficial venous reflux was made based on findings from duplex scans rather than the presence of visible varicosities.

All patients had primary venous insufficiency. Patients with post-thrombotic syndrome were excluded from the study. Venous ulcers developed in all patients for the first time. All patients had su-

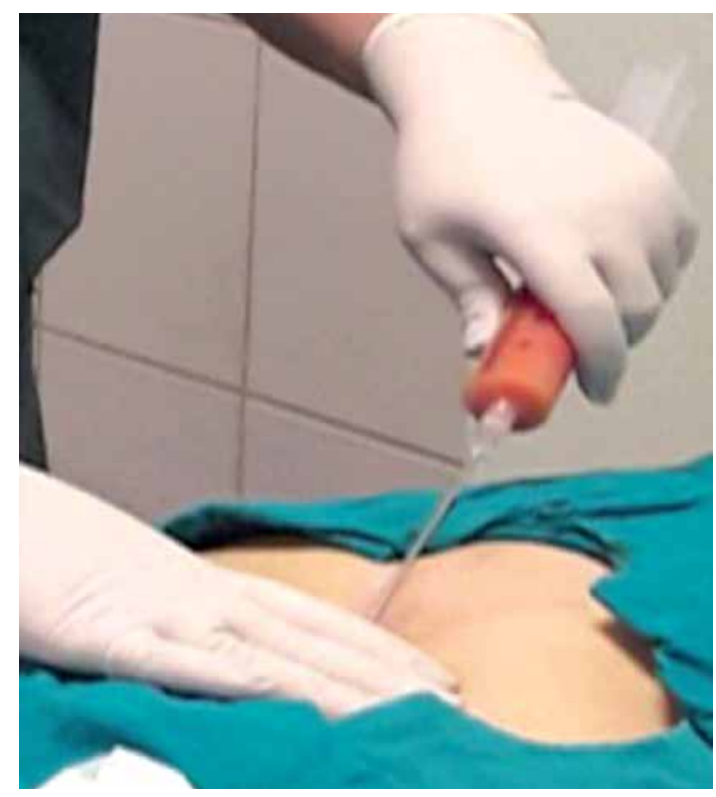

Figure 1. Adipose tissue aspiration perficial venous insufficiency. Superficial venous insufficiency has been accepted as having a great saphenous vein diameter of $5.5-10 \mathrm{~mm}$ and a reflux duration over $1 \mathrm{~s}$. A perforator vein was identified as incompetent if it was larger than $3 \mathrm{~mm}$ in diameter and demonstrated reverse or bidirectional flow for more than $0.5 \mathrm{~s}$ with compression and release. Perforator incompetence was identified in 11 patients. All limbs had a normal deep venous system. All saphenous veins were treated with endovenous RF ablation. When a patient had both saphenous vein reflux and perforating vein reflux, simultaneous treatment, endovenous RF ablation and perforating vein ligation were scheduled, and the effect of each treatment was explained to the patient. Perforating vein locations were marked on the skin preoperatively by duplex scanning. Then, subfascial ligation of perforating veins was performed through a small incision. Peripheral arterial pulse examination and ankle brachial index measurements were performed in all patients before the procedure to exclude peripheral arterial disease. Diabetes mellitus was excluded in all patients. The distribution of descriptive properties is summarized in Table I. Thirty-one patients who were included in the study were treated for venous insufficiency and venous ulcer with surgical treatment. Patients who did not show benefit with treatment of venous ulcer after 6 months of surgery were included in the study. Despite surgical treatment for underlying pathology of venous ulcers that was examined in a group of patients in the non-healing group, it was found that patients had general wound care problems. A total of 18 $(58 \%)$ patients had body mass index $>30 \mathrm{~kg} / \mathrm{m}^{2}$.

At the beginning of the operation, $100 \mathrm{ml}$ of fat aspiration was obtained from the abdominal region under local anesthesia. Using the MyStem Regenerative Adipose-Derived Stem Cell Purification Kit (MyStem LLC, USA), $20 \mathrm{ml}$ of stromal vascular fraction cells were isolated from fat tissue and injected into and around the venous ulcer area (Figures 1 and 2). Venous ulcers of all patients were debrided prior to fat injection. No

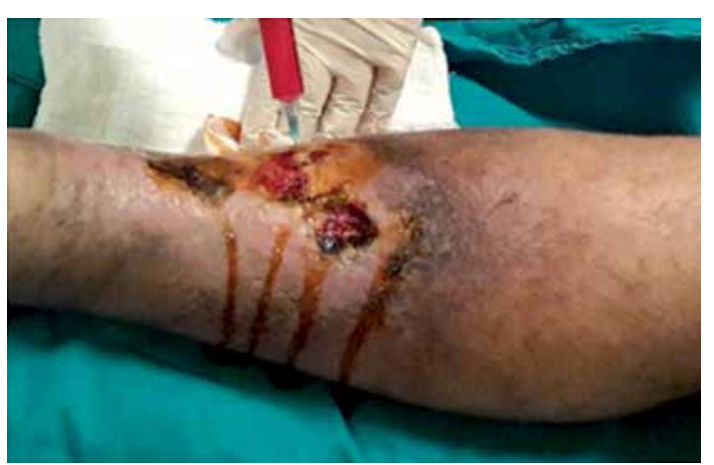

Figure 2. Adipose-derived autologous stem cells injection and venous leg ulcer 
wound care product was used after the procedure. All patients were treated with an elastic bandage for 10 days after the procedure. In the study, all patients were treated with stem cells only once and calcium dobesilate $1000 \mathrm{mg}$ and pentoxifylline $600 \mathrm{mg}$ per day were applied for 6 months besides stem cell treatment.

After the operation, patients were prescribed class 2 elastic stockings (Medi, Hereford) and advised to wear these during the day. All patients were given standard written and verbal advice to elevate the affected leg and exercise.

Ulcer diameters were measured and recorded in the $3^{\text {rd }}, 6^{\text {th }}$ and $12^{\text {th }}$ months. After ulcer healing, patients were subject to a 1-year follow-up period to assess recurrence. Ulcer healing was defined as complete re-epithelialization of the leg. We defined any breakdown of epithelium after ulcer healing as ulcer recurrence.

\section{Statistical analysis}

Statistical analysis was performed using the NCSS (Number Cruncher Statistical System) 2007 (Kaysville, Utah, USA) software program. The Mann-Whitney $U$ test was used for two-group comparisons of variables lacking a normal distribution. The Wilcoxon sign test is a statistical comparison of the average of two dependent samples. Fisher's exact test was used for comparison of qualitative data. Significance was defined as $p<0.05$.

\section{Results}

In all cases, changes in ulcer area measurements were statistically significant ( $p=0.001$; $p<0.01)$. The decrease percentage of the ulcer size decrease ratio of the $3^{\text {rd }}$ and $6^{\text {th }}$ months are statistically significant. While the decrease ratio at the $3^{\text {th }}$ month was $62.97 \%(p=0.001 ; p<0.01)$, it has been detected as $85.6 \%$ at the $6^{\text {th }}$ month $(p=0.001 ; p<0.01)$. The decrease of the ulcer size from the $3^{\text {rd }}$ month to the $6^{\text {th }}$ month has been determined as $64.47 \%$ which has been found statistically significant $(p=0.001 ; p<0.01)$.

The follow-up time was 12 months after ulcer healing. Eighteen ulcers demonstrated complete healing at the $12^{\text {th }}$ month. Thirteen ulcers experienced serious contraction and epithelialization even though the ulcer was not completely closed. The ulcer size at the $12^{\text {th }}$ month was reduced by $96.00 \pm 1.74 \%$ in these patients. The reductions in ulcer area measurements according to month are presented in Table II. The reduction in ulcer area measurements was significant $(p=0.001 ; p<0.01)$.

Patients were divided into two groups based on the 12-month healing status: the group with complete healing and the group with reduced $u$ cer size. We assessed whether a significant association existed between total healing and patient parameters.

Between the complete healing group and the group with reduced ulcer size:

Table II. Ulcer size reduction at $3^{\text {rd }}, 6^{\text {th }}$ and $12^{\text {th }}$ month. The reduction in ulcer area according to the months was statistically significant $(p=0.001 ; p<0.01)$

\begin{tabular}{|c|c|c|c|c|c|}
\hline \multicolumn{2}{|c|}{ Ulcer size measurement $\left[\mathrm{cm}^{2}\right]$} & \multirow[t]{2}{*}{ Total } & \multicolumn{2}{|c|}{ Healing status } & \multirow[t]{2}{*}{$P$-value ${ }^{\mathrm{a}}$} \\
\hline & & & Healing $(+)(n=18)$ & Healing $(-)(n=13)$ & \\
\hline \multirow{2}{*}{$\begin{array}{l}\text { Beginning } \\
\text { ulcer size }\end{array}$} & Min.-max. (median) & $10-54(30)$ & $10-49(26.5)$ & $24-54(42)$ & \multirow[t]{2}{*}{$0.010^{*}$} \\
\hline & Mean \pm SD & $32.48 \pm 13.15$ & $27.16 \pm 12.77$ & $39.84 \pm 10.02$ & \\
\hline \multirow[t]{2}{*}{$3^{\text {rd }}$ month } & Min.-max. (median) & $3-28(10)$ & $3-16(6)$ & $9-28(24)$ & \multirow[t]{2}{*}{$0.001^{* *}$} \\
\hline & Mean \pm SD & $12.48 \pm 7.84$ & $7.83 \pm 4.39$ & $18.92 \pm 7.00$ & \\
\hline \multirow[t]{3}{*}{$6^{\text {th }}$ month } & Min.-max. (median) & $1-16(3)$ & $1-9(2)$ & $3-16(8)$ & \multirow[t]{2}{*}{$0.001^{\star *}$} \\
\hline & Mean \pm SD & $5.12-3 \pm 7.84$ & $2.39 \pm 2.09$ & $8.92 \pm 4.84$ & \\
\hline & $P$-value & $0.001^{\star *}$ & $0.001^{* *}$ & $0.001^{\star *}$ & \\
\hline \multicolumn{6}{|c|}{$\%$ Ulcer size change } \\
\hline \multirow{3}{*}{$\begin{array}{l}3^{\text {rd }} \text { month- } \\
\text { beginning } \\
\text { size }\end{array}$} & Min.-max. (median) & $31.4-86.7(66.6)$ & $37.5-86.7(72.5)$ & $31.4-75(52)$ & \multirow[t]{2}{*}{$0.001^{* *}$} \\
\hline & Mean \pm SD & $62.97 \pm 14.41$ & $70.21 \pm 11.42$ & $52.95 \pm 12.10$ & \\
\hline & $P$-value (beginning-3rd month)d $^{\text {(bin }}$ & $0.001^{\star *}$ & $0.001^{\star *}$ & $0.001^{* *}$ & \\
\hline \multirow{3}{*}{$\begin{array}{l}6^{\text {th }} \text { month- } \\
\text { beginning } \\
\text { size }\end{array}$} & Min.-max. (median) & $62.5-96.7(90)$ & $62.5-96.7(92.7)$ & $66.7-91.7(77)$ & \multirow[t]{2}{*}{$0.001^{* *}$} \\
\hline & Mean \pm SD & $85.60 \pm 10.45$ & $90.96 \pm 7.47$ & $78.19 \pm 9.56$ & \\
\hline & $P$-value (beginning-6th month)d & $0.001^{* *}$ & $0.001^{* *}$ & $0.001^{* *}$ & \\
\hline \multirow{3}{*}{$\begin{array}{l}6^{\text {th }} \text { month }- \\
3^{\text {rd }} \text { month }\end{array}$} & Min.-max. (median) & $33.3-83.3(66.7)$ & $40-83.3(75)$ & $33.3-70(60)$ & \multirow[t]{2}{*}{$0.001^{* *}$} \\
\hline & Mean \pm SD & $64.47 \pm 14.06$ & $71.40 \pm 9.48$ & $54.89 \pm 13.98$ & \\
\hline & $P$-value ${ }^{(3 r d \text { month-6th month)d }}$ & $0.001^{* *}$ & $0.001^{* *}$ & $0.001^{* *}$ & \\
\hline
\end{tabular}

a Mann-Whitney $U$ test, ${ }^{c}$ Friedman test, ${ }^{d}$ Wilcoxon signed ranks test, ${ }^{*} p<0.05,{ }^{* *} p<0.01$. 


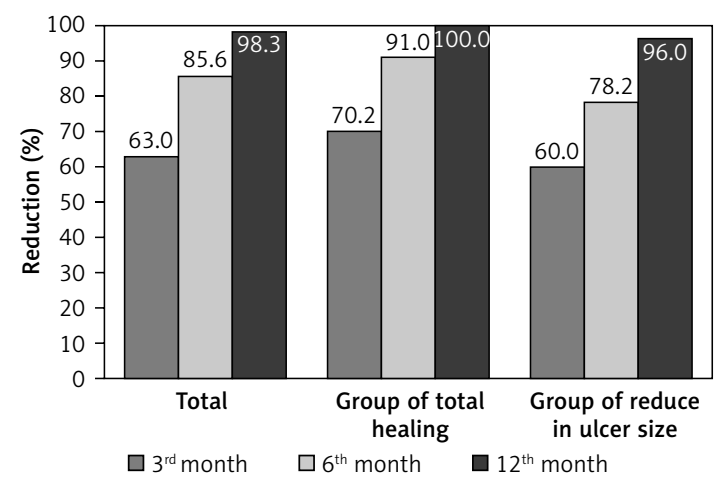

Figure 3 . Ulcer size reduction at $3^{\text {rd }}, 6^{\text {th }}$ and $12^{\text {th }}$ month. The reduction in ulcer area according to the months was statistically significant $(p=0.001$; $p<0.01)$

- No statistically significant difference was noted according to age distribution $(p>0.05)$.

- No statistically significant difference was noted according to sex $(p>0.05)$.

- No statistically significant difference was noted between initial ulcer size measurements $(p>0.05)$.

When the rates of healing were evaluated according to the time in months, the reduction in ulcer area at the $3^{\text {rd }}$ month was $62.97 \pm 14.41 \%$. The reduction in ulcer area at the $6^{\text {th }}$ month was $85.60 \pm 10.45 \%$. At 12 months, complete recovery was observed in $58.1 \%$ of the patients, and $41.9 \%$ of patients exhibited a $96.00 \pm 1.74 \%$ reduction in ulcer area. The reduction in ulcer area according to the month was statistically significant $(p=0.001$; $p<0.01$ ) (Figure 3).

After the ulcers were healed, the patients received follow-up for recurrence assessment for 1 year. Recurrent ulcers were observed at treated sites in 3 of 31 patients (9\%). No adverse events, such as infection, inflammation, and tissue reactions, were observed (Figures 4 and 5).

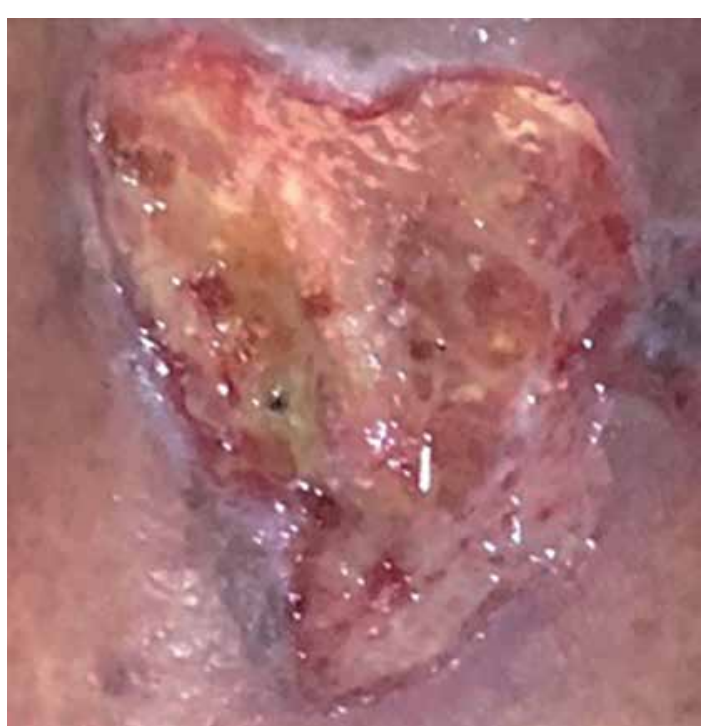

Figure 4. Leg ulcer $36 \times 40 \mathrm{~mm}$

\section{Discussion}

Incompetent perforating veins play specific roles in venous ulcers and recurrent varicose veins [17]. The numbers of incompetent veins and diameters of perforating veins are increased in patients presenting with venous ulcers [18]. Improved venous ulcer healing and calf function were observed in patients with combined treatment of superficial and perforating veins compared with patients who exclusively underwent superficial vein treatment [19]. Current guidelines recommend perforator treatment in cases of CEAP pathophysiology scores of 5 and 6.

We used radiofrequency ablation to treat varicose veins in all patients in our study and performed perforating vein ligation exclusively in patients in whom perforator insufficiency was detected in the duplex scan to increase venous ulcer healing and reduce recurrence.

We performed subfascial perforating vein ligation after marking the incompetent perforating vein location on the skin via preoperative duplex scanning. This is a simple and effective procedure for treating perforating veins through a small incision [20]. Most incompetent perforating veins can be identified and ligated through duplex-guided localization. Pierik demonstrated that duplex-guided localization of lower leg perforating veins exhibits $79.2 \%$ sensitivity and $100 \%$ specificity in detecting perforating veins [18]. In 1970, Folse and Alexander used Doppler imaging rather than clinical examination to localize the perforating veins, and all perforating veins were ligated through a small incision [21].

Despite appropriate treatment, chronic venous ulceration (CVU) typically has a protracted course of healing and can recur numerous times [18]. The CVU healing rate is very variable in the literature (35-85\%), and different articles report a significant proportion of recalcitrant ulceration, which responds to treatment but does not heal [22]. Many theories have been postulated to explain

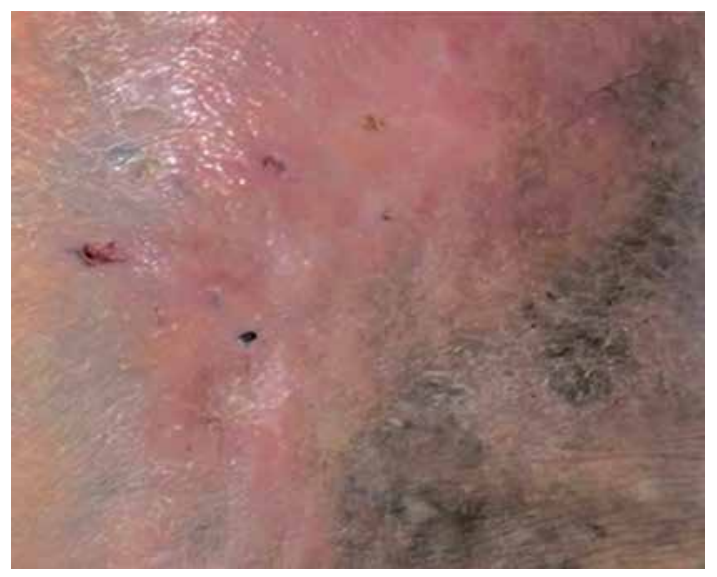

Figure 5. Complete recovery leg ulcer $36 \times 40 \mathrm{~mm}$ 
the pathogenesis of venous ulceration. The skin ulcers may occur because venous hypertension results in tissue hypoxia, tissue damage, wound exudate, a reduction in partial oxygen pressure, colonization and uncontrolled microbial growth [23].

Different treatment modalities are needed to improve blood flow to the affected site. One of the therapeutic alternatives in refractory venous leg ulcers is platelet-rich plasma (PRP) [24]. Woźniak et al. [24] used PRP to improve ulcer healing for venous leg ulcers. They reported that platelet-rich plasma possibly inhibits growth of many bacterial species, and ulcerations to which platelet rich plasma was applied tended to heal better.

In recent years, stem cells have been extensively researched for their wound healing potential in both preclinical and clinical settings, and a beneficial effect was observed $[25,26]$. However, these studies mainly focused on ischemic wounds, diabetic wounds and irradiated wounds [25]. In this study, we examined the effect of adipose-derived stem cells (ASCs) in wound healing on a case series consisting entirely of venous leg ulcers.

Adipose-derived stem cells include a reasonably large number of multipotent cells that can easily be isolated from lipoaspirated fat by a series of filtration and centrifugation steps to obtain the cellular fraction that is used for regenerative medicine $[27,28]$.

Adipose-derived stem cells promote angiogenesis, secrete growth factors, regulate the inflammatory process, and differentiate into multiple cell types, which is required for ideal wound healing. Adipose-derived stem cells secrete almost all growth factors that participate in normal wound healing, such as VEGF, keratinocyte growth factor, fibroblast growth factor-2, hepatocyte growth factor, epidermal growth factor, and platelet-derived growth factor $[29,30]$. The expression of these factors increases when ASCs are exposed to hypoxic conditions, and the beneficial effect on wound healing can be improved $[29,30]$. The secretory activity of ASCs was demonstrated in animal models. These results suggest the creation of the necessary environment to overcome the chronic inflammatory state and initiate tissue regeneration. Additionally, ASCs can promote human dermal fibroblast proliferation by directly contacting cell and paracrine activation in the reepithelialization phase of wound healing. Furthermore, ASCS in the wound can result in augmentation of the local blood supply and improvements in regeneration capacity. Recently, Kim et al. demonstrated that ASCs also have antioxidant effects in wound healing [31].

The advantages of ASCs compared with other mesenchymal stem cells (MSCs), such as bone marrow-derived (BM-MSCs), include ease of harvesting considerably increased numbers with simi- lar differential potential and regenerative capacity as the BM-MSCs. Subcutaneous adipose tissue is abundant and readily accessible to harvest via a liposuction procedure. Liposuction is less invasive than bone marrow aspiration, and plastic surgeons can easily perform the procedure, resulting in less patient discomfort and donor-site morbidity.

The amount of stem cells in $1 \mathrm{~g}$ of adipose tissue is estimated to be 500 -fold increased compared with the number of MSCs in $1 \mathrm{~g}$ of bone marrow [32]. As such, adipose tissue can be considered the richest and most accessible source of stem cells.

Isolation of ASCs from adipose tissue is a relatively simple process when it is performed in cell biology laboratories. However, at the point of care for immediate clinical administration, stromal vascular fraction (SVF) can be preferred. The SVF derived from adipose tissue contains heterogeneous cell populations, such as mesenchymal progenitor/stem cells, preadipocytes, endothelial cells, pericytes, T cells, and M2 macrophages. Isolation of SVF in clinical administration requires a special methodology to prevent contamination and comply with regulatory requirements. Aronowitz et al. [33] discussed the processes that can be used to separate SVF cells from fat tissue in their review. They compared two isolation methods, mechanical and enzymatic. They reported that the SVF isolated through mechanical methods is equally as safe as the extracellular matrix obtained with proteolytic enzymes. Additionally, the process is less costly and less time consuming, but the product contains more blood mononuclear cells and fewer progenitor cells. Mechanical methods can provide a low-cost, rapid and simple alternative to enzymatic isolation methods. In our series, we used ASCs obtained using the MyStem Regenerative Adipose-Derived Stem Cell Purification Kit (MyStem LLC, USA) [34], which is based on GMP-proof, non-enzymatic tissue separation, enabling rapid (10-15 min) isolation from human stromal tissues in a closed sterile system.

Different delivery methods for ASC treatment have been examined, such as systemic administration, local injection, and topical application, and many different scaffolds have been used [25]. Given the lack of comparative studies, no consensus exists on which delivery method is superior. We used the local injection model because it is easy to apply independently of patient compliance.

The CVU healing rate is very variable in the literature (35-85\%) [18]. Barwell et al. [18] compared surgery and compression with compression alone in chronic venous ulceration (ESCHAR study) in a randomized controlled trial. The researchers reported $56-66 \%$ healing rates of this disorder at 24 weeks. In our study, none of the ulcers were completely healed at 24 weeks. However, at 
24 weeks, our ulcer size reduction rate was 85.60 $\pm 10.45 \%$. We cannot say ASC injection provides any additional benefit in terms of time of venous ulcer healing based on data from our study.

It is a common reality that the rate of venous ulcer recurrence is high. In 1995, a comparison of several studies from different care settings in the United Kingdom reported that leg ulcer recurrence rates ranged from $22 \%$ to $69 \%$ [35]. More recently, recurrence rates for venous ulcers were reported to range from $26 \%$ to $69 \%$ at 12 months [36].

Barwell et al. reported that recurrence rates were $28 \%$ with compression therapy and 14\% with surgical treatment at 12 months in a randomized controlled trial. In our study, recurrence was observed in only 3 patients of 31 patients at the 1 -year follow-up. This figure, which corresponds to $9 \%$, is lower than other reported recurrence rates in the literature. The decrease in the recurrence rate can be interpreted as dependent on the effect of stem cells on wound healing given their angiogenic and regenerative capacity. Although we think that these findings are encouraging, there is a need for wider randomized controlled studies to arrive at a definitive conclusion.

Although the mechanism of action of stem cells on wound healing is not fully understood, many experimental studies have shown that the wound microenvironment stimulates stem cells originating from adipose tissue and marrow tissue, while at the same time allowing the migration of those cells to the site [37]. On the other hand, stem cells, cytokine, paracrine and autocrine effects and revascularization around the wound, increase in available vessels and modulate the inflammatory process with fibroblast keratinocyte cell generation. All of these factors ultimately bring the wound microcirculation to a healthy state and allow wound healing to be achieved [38]. In hypoxic conditions (common in chronic wounds), stem cells secrete angiogenic and fibroblast growth factors, and the proliferation rate of stem cells increases. On the other hand, angiogenesis also stimulates endothelial progenitor cells and neovascularization occurs interactively [38]. Endothelial progenitor cells come from the source of bone marrow and fat tissue. Endothelial cells are stimulated by "shear stress" in the bloodstream and matrix ligand binding releasing a cascade of metalloproteins [39] and by the presence of a hypoxic environment in the wound and an increase in the level of stromal factor, and finally these cells reach the cutaneous lesion area [39]. In fact, this mechanism does not work in diabetic and elderly patients [40]. Therefore, current regenerative treatment approaches can be summarized as the iatrogenic addition of high numbers of stem cells to the affected area in unhealed wounds. In a study by Moreno-Eutimio et al., the use of a carbohydrate polymer with zinc oxide improved healing and quality of life of patients and reduced inflammation in patients with CVU when used with standard venous compression treatment. Autogenously derived regenerative cell therapy applications besides that kind of supportive therapy would be beneficial for wound care [41].

In conclusion, the application of cell therapy in venous leg ulcer is currently used exclusively in patients not responding to the standard treatment. Autogenously derived regenerative cell therapy for VLUs can be considered as additional to primary surgical treatment. The results of the study show that regenerative cell therapy does not shorten the venous recovery period but decreases the 1-year recurrence rates according to the literature. However, randomized controlled clinical trials must be conducted to develop future innovations for treatment.

\section{Acknowledgments}

We would like to thank Emire Bor (Empiar Statistics) for performing the statistical analysis of the study.

\section{Conflict of interest}

The authors declare no conflict of interest.

\section{References}

1. Lazarus G, Valle MF, Malas M, et al. Chronic venous leg ulcer treatment: future research needs. Wound Repair Regen 2014; 22: 34-42. Erratum in: Wound Repair Regen 2014; 22: 291.

2. Van Gent WB, Wilschut ED, Wittens C. Management of venous ulcer disease. BMJ 2010; 341: c6045.

3. Kelly T, Yang W, Chen CS, Reynolds K, He J. Global burden of obesity in 2005 and projections to 2030. Int J Obes (Lond) 2008; 32: 1431-7.

4. Lo YF, Yang CH. Stripping and ligation of the saphenous vein. Semin Cutan Med Surg 2005; 24: 200-8.

5. Szendro G, Nicolaides AN, Zukowski AJ, et al. Duplex scanning in the assessment of deep venous incompetence. J Vasc Surg 1986; 4: 237-42.

6. Hanrahan LM, Kechejian GJ, Cordts PR, et al. Patterns of venous insufficiency in patients with varicose veins. Arch Surg 1991; 126: 687-90.

7. Zollino I, Zuolo M, Gianesini S, et al. Autologous adipose-derived stem cells: basic science, technique, and rationale for application in ulcer and wound healing. Phlebology 2017; 32: 160-71.

8. Coleridge-Smith P, Labropoulos N, Partsch H, Myers K, Nicolaides A, Cavezzi A. Duplex ultrasound investigation of the veins in chronic venous disease of the lower limbs-UIP concensus document. Part I. Basic principles. Eur J Vasc Endovasc Surg 2006; 31: 83-92.

9. Agrifoglio G, Edwards EA. Results of surgical treatment of varicose veins: one- to fourteen-year follow-up study of 416 patients. JAMA 1961; 178: 906-11.

10. Fraser JK, Wulur I. Fat tissue: an underappreciated source of stem cells for biotechnology. Trends Biotechnol 2006; 24: 150-4. 
11. Min RJ, Khilnani NM, Golia P. Duplex ultrasound evaluation of lower extremity venous insufficiency. J Vasc Interv Radiol 2000; 14: 1233-41.

12. De Ugarte DA, Morizono K, Elbarbary A, et al. Comparison of multi-lineage cells from human adipose tissue and bone marrow. Cells Tissues Organs 2003; 174: 101-9.

13. Sensebe L, Bourin P. Mesenchymal stem cells for therapeutic purposes. Transplantation 2009; 87: S49-53.

14. Baglioni S, Francalanci M, Squecco R, et al. Characterization of human adult stem-cell populations isolated from visceral and subcutaneous adipose tissue. FASEB 2009; 23: 3494-505.

15. Hassan WU, Greiser U, Wang W. Role of adipose-derived stem cells in wound healing. Wound Repair Regen 2014 22: 313-25.

16. Kim WS, Park BS, Sung JH. The wound-healing and antioxidant effects of adipose-derived stem cells. Expert Opin Biol Ther 2009; 9: 879-87.

17. van Neer PA, Veraart JC, Neumann HA. Venae perforantes: a clinical review. Dermatol Surg 2013; 29. 931-42.

18. Barwell JR, Davies CE, Deacon J, et al. Comparison of surgery and compression with compression alone in chronic venous ulceration (ESCHAR study): randomised controlled trial. Lancet 2004; 363: 1854-9.

19. Iafrati MD, Pare GJ, O’Donnell TF, Estes J. Is the nihilistic approach to surgical reduction of superficial and perforator vein incompetence for venous ulcer justified? J Vasc Surg 2002; 36: 1167-74.

20. Royle JP. Recurrent varicose veins. World J Surg 1986; 10: 944-53.

21. Folse R, Alexander RH. Directional flow detection for localizing venous valvular incompetency. Surgery 1970; 67: 114-21.

22. Mauck KF, Asi N, Undavalli C, et al. Systematic review and meta-analysis of surgical interventions versus conservative therapy for venous ulcers. J Vasc Surg 2014 60: 60S-70S.e1-2.

23. Pappas PJ, Lal BK, Ohara N, Saito S, Zapiach L, Durán WN. Regulation of matrix contraction in CVI patients. Eur J Endovasc Surg 2009; 38: 518-29.

24. Woźniak W, Tarnas M, Miłek T, Mlosek KR, Ciostek P. The effect of local platelet rich plasma therapy on the composition of bacterial flora in chronic venous leg ulcer. Pol J Microbiol 2016; 65: 353-7.

25. Toyserkani NM, Christensen ML, Sheikh SP, Sorensen JA. Adipose-derived stem cells: new treatment for wound healing? Ann Plast Surg 2015; 75: 117-23.

26. Kirana S, Stratmann B, Lammers D, et al. Wound therapy with autologous bone marrow stem cells in diabetic patients with ischaemia-induced tissue ulcers affecting the lower limbs. Int J Clin Pract 2007; 61: 690-4.

27. Strem BM, Hicok KC, Zhu M, et al. Multipotential differentiation of adipose tissue-derived stem cells. Keio J Med 2005; 54: 132-41.

28. Zuk PA, Zhu M, Ashjian P, et al. Human adipose tissue is a source of multipotent stem cells. Mol Biol Cell 2002 13: 4279-95.

29. Ebrahimian TG, Pouzoulet F, Squiban C, et al. Cell therapy based on adipose tissue-derived stromal cells promotes physiological and pathological wound healing. Arterioscler Thromb Vasc Biol 2009; 29: 503-10.

30. Nie C, Yang D, Xu J, Si Z, Jin X, Zhang J. Locally administered adipose-derived stem cells accelerate wound healing through differentiation and vasculogenesis. Cell Transplant 2011; 20: 205-16.
31. Kim WS, Park BS, Sung JH. The wound-healing and antioxidant effects of adipose-derived stem cells. Expert Opin Biol Ther 2009; 9: 879-87.

32. Fraser JK, Wulur I, Alfonso Z, Hedrick MH. Fat tissue: an underappreciated source of stem cells for biotechnology. Trends Biotechnol 2006; 24: 150-4.

33. Aronowitz JA, Lockhart RA, Hakakian CS. Mechanical versus enzymatic isolation of stromal vascular fraction cells from adipose tissue. Springerplus 2015; 4: 713.

34. Oberbauer E, Steffenhagen C, Wurzer C, Gabriel C, Redl H, Wolbank S. Enzymatic and non-enzymatic isolation systems for adipose tissue-derived cells: current state of the art. Cell Regen (Lond) 2015; 4: 7.

35. Moffatt CJ, Dorman MC. Recurrence of leg ulcers within a community leg ulcer service. J Wound Care 1995; 4: 57-61.

36. Nelson EA, Cullum N, Jones J. Venous leg ulcers. Br Med J (Clin Res Ed) 2006; 172: 1447-52.

37. Kässmeyer S, Plendl J, Custodis P, Bahram-soltani M. New insights in vascular development: vasculogenesis and endothelial progenitor cells. Anat Histol Embryol 2009; 38: 1-11.

38. Badillo AT, Redden RA, Zhang L, Doolin EJ, Liechty KW. Treatment of diabetic wounds with fetal murine mesenchymal stromal cells enhances wound closure. Cell Tissue Res 2007; 329: 301-11.

39. Grayson WL, Zhao F, Bunnell B, Ma T. Hypoxia enhances proliferation and tissue formation of human mesenchymal stem cells. Biochem Biophys Res Commun 2007; 358: 948-53.

40. Capla JM, Grogan RH, Callaghan MJ, et al. Diabetes impairs endothelial progenitor cell-mediated blood vessel formation in response to hypoxia. Plast Reconstr Surg 2007; 119: 59-70.

41. Moreno-EutimioMA,Espinosa-MonroyL,Orozco-AmaroT, et al. Enhanced healing and anti-inflammatory effects of a carbohydrate polymer with zinc oxide in patients with chronic venous leg ulcers: preliminary results. Arch Med Sci 2018; 14: 336-44. 